\title{
The New View on Ignorance Undefeated
}

\author{
Rik Peels
}

Received: 23 February 2012 / Accepted: 27 February 2012 /

Published online: 16 March 2012

(C) The Author(s) 2012. This article is published with open access at Springerlink.com

\begin{abstract}
In this paper, I provide a defence of the New View, on which ignorance is lack of true belief rather than lack of knowledge. Pierre Le Morvan has argued that the New View is untenable, partly because it fails to take into account the distinction between propositional and factive ignorance. I argue that propositional ignorance is just a subspecies of factive ignorance and that all the work that needs to be done can be done by using the concept of factive ignorance. I also defend two arguments of mine in favour of the New View against Le Morvan's criticisms. As to the Linguistic Argument, I point out that the intuitions of the adherent of the New View about cases of true belief that fall short of knowledge are really intuitions about factive rather than propositional ignorance. As to the Excuse Argument, I argue that true belief is exculpatorily relevant: a true belief in a proposition $p$, where disbelief that $p$ or suspension on $p$ would provide at least a partial excuse, is relevant in that it renders one blameworthy for one's action, unless further excuses hold. Finally, I reply to two closely related objections that might be levelled against the New View, namely that it seems false that one can reduce one's ignorance by arbitrarily believing as many propositions as possible and that it seems false that an intellectually conscientious and critical person is more ignorant than an intellectually sloppy and credulous person just because the latter has more true beliefs.
\end{abstract}

Keywords Excuse argument · Ignorance - Lack of knowledge - Lack of true belief . Linguistic argument $\cdot$ New view $\cdot$ Standard view

R. Peels $(\bowtie)$

Department of Philosophy, University of Utrecht, Utrecht, Netherlands e-mail: rik.peels@phil.uu.nl 


\section{Introduction}

In two recent papers in this journal, I have argued that there are at least two good reasons to think that ignorance is lack of true belief rather than lack of knowledge. ${ }^{1}$ This idea has been criticized by Pierre Le Morvan in two recent articles in this journal. In his most recent piece, entitled "On Ignorance: A Vindication of the Standard View", he argues that my first argument is defective because it fails to distinguish between factive and propositional ignorance. He also defends the claim that my second argument is wanting because it fails to acknowledge that certain kinds of ignorance are exculpatorily irrelevant. In this paper, I show why Le Morvan's criticisms do not hold water and defend the New View on ignorance against two further objections that might be levelled against it. ${ }^{2}$

\section{Factive and Propositional Ignorance}

According to Le Morvan, we should distinguish between factive and propositional ignorance. $^{3} \mathrm{He}$ does not give any precise definitions of these two varieties of ignorance, but he seems to have the following in mind. Factive ignorance is ignorance of the truth of some specific proposition $p$, that is, ignorance that $p$ is true or, in other words, ignorance that the truth-conditions of $p$ are satisfied. Propositional ignorance of $p$, on the other hand, is ignorance of $p$ itself, roughly, ignorance of what the truth-conditions of $p$ are (at least, on Le Morvan's view, it entails such ignorance). One can only believe that $p$, then, if one is not propositionally ignorant of $p$, although one may well be factively ignorant of $p$ and yet believe that $p$. Thus, if I consider the proposition $q$ that calcium is the atomic element with number 20, it follows that I am not propositionally ignorant of $q$, even though I may very well be factively ignorant of $q$, for instance, because I do not believe this truth. ${ }^{4}$

In my reply to Le Morvan, I claimed that the concept of propositional ignorance is unnatural in the sense that we do not use the word 'ignorant' in that sense in ordinary language. Le Morvan replies that it makes perfect sense to distinguish between

\footnotetext{
${ }^{1}$ See Peels 2010; 2011.

${ }^{2}$ Le Morvan also criticizes my earlier account of dispositional beliefs, on which one can believe a proposition $p$ even if one has never considered $p$. Le Morvan maintains that one can believe a proposition $p$ only if one has considered $p$ at some point in one's life. We should notice that this claim is in tension with both the Standard View and the New Views on ignorance. For, according to both views, absence of true belief is a sufficient condition for ignorance. But it seems that many people are not ignorant of propositions that they have never considered. Take the proposition that one is less that $500 \mathrm{ft}$ tall. If one believes that proposition only if one has considered it at some point, then on both the Standard and New Views, most people are ignorant that they are less than $500 \mathrm{ft}$ tall, for most people have never considered this proposition. But that seems an outrageous claim: surely, most people are not ignorant that they are less than $500 \mathrm{ft}$ tall. On the contrary, adult and properly functioning human beings truly believe and even know that they are less than $500 \mathrm{ft}$ tall.

${ }^{3}$ See Le Morvan 2011; 2012.

${ }^{4}$ When I said that "to be ignorant of a proposition is not to be ignorant of its truth, although it entails such ignorance if the proposition is true" (Peels 2011, 349) I meant that, on Le Morvan's view, to be propositionally ignorant is not identical to being factively ignorant, even though propositional ignorance of $p$ entails factive ignorance of $p$. The entailment holds because if you do not know or truly believe what the truth-conditions of a proposition are, then you cannot truly believe that proposition.
} 
ignorance of a proposition's truth-conditions and ignorance of whether or not a proposition's truth-conditions are satisfied. I agree: that distinction makes sense. What I was claiming, however, was merely that if we say in ordinary language that " $S$ is ignorant that $p$ ", we always mean that $S$ is ignorant that $p$ is true. Sometimes, such factive ignorance will be accompanied by propositional ignorance. Thus, an uneducated bushman will be both factively and propositionally ignorant that glucose is composed of $\mathrm{C}_{6} \mathrm{H}_{12} \mathrm{O}_{6}$. But I only claimed that if we say that $S$ is ignorant that $p$, we claim that $S$ is ignorant of the truth of $p$. In saying that $S$ is ignorant that $p$, we never claim that $S$ is merely ignorant of the truth-conditions of $p$.

I also suggested that we do not need the concept of propositional ignorance, because we can understand all cases of ignorance in terms of factive ignorance. That still seems right to me. Ignorance of the truth-conditions $T C$ of some proposition $p$ is ignorance that $T C$ are the truth-conditions of $p$ and that is an instance of factive ignorance. Thus, propositional ignorance is merely a subspecies of factive ignorance. As long as Le Morvan has not told us anything else about propositional ignorance than that it entails ignorance of the truth-conditions of a proposition, we have no reason to think that propositional ignorance is distinct from factive ignorance-for all we know, propositional ignorance is a particular kind of factive ignorance. All the work that needs to be done can be done by using the concept of factive ignorance, where ignorance is to be spelled out as it is spelled out by the New View: ignorance is absence of true belief.

Le Morvan argues that the New View, which implies that one can only be ignorant of truths, is false for at least four reasons. First, I suggested that someone who falsely believes that $p$ - that is, believes the false proposition $p$ - is not ignorant of $p$, that is, of $p$ 's truth. And that is simply because $p$ is not true. Le Morvan claims that this contradicts my assertion that someone who does not believe $p$ when $p$ is true is ignorant that $p$. Here is his argument:

1. ( $S$ believes that $p) \& \sim p$. [ass.]

2. $\sim p$. [(1), simplification]

3. $\sim p \mathrm{v} \sim(S$ believes that $p)$. [(2), addition]

4. $p \rightarrow \sim(S$ believes that $p)$. [(3), logical equivalence $]$

I said that if someone fails to believe that $p$ when $p$ is true, then that person is ignorant that $p$. However, if premise (1) is true, that is, if someone falsely believes that $p$, then, contrary to what I said, that person is ignorant that $p$, for that follows from (4) in conjunction with the New View. Le Morvan further says that I could avoid this problem by acknowledging that someone who falsely believes that $p$ is not propositionally ignorant of $p$, but nonetheless factively ignorant that $p$.

This argument fails for several reasons. Here, I confine myself to what I consider to be the most important reason. The conclusion, proposition (4), says that if $p$ is or were true, $S$ would not believe that $p$-and, hence, would be ignorant that $p$. It does not say that $S$ is ignorant that $p$, because the conclusion does not say that $p$ is true. When I said that $S$ is ignorant that $p$ if and only if $S$ fails to believe that $p$ is true, I meant that $S$ is ignorant that $p$ if and only if $<S$ fails to believe that $p \& p$ is true $>$, not that $S$ is ignorant that $p$ if and only if $<$ if $p$ were true, then $S$ would fail to believe that $p>$. Saying that $S$ is not ignorant that $p$ when $p$ is false is perfectly compatible with saying that $S$ would be ignorant that $p$ if $p$ were true. Thus, we do not need the 
distinction between propositional and factive ignorance to avoid the consequence that someone who falsely believes that $p$ is ignorant that $p$.

Second, I claimed that when philosophers say that someone believes that $p$, knows that $p$, doubts that $p$, or is ignorant that $p$, they mean that $S$ believes that $p$ is true, that $S$ knows that $p$ is true, that $S$ doubts that $p$ is true, and that $S$ is ignorant that $p$ is true. Le Morvan replies that, even though this may be correct, those same philosophers would be willing to distinguish between propositional ignorance and factive ignorance. I am happy to concede that they would; I am one of them. Only, the distinction would merely be one between genus and species: one can still maintain that propositional ignorance is a subspecies of factive ignorance. My point was that using the word 'ignorant' for instances of propositional rather than factive ignorance is highly unnatural in the sense that neither in ordinary language nor in philosophical language we ever mean that $S$ is propositionally ignorant that $p$ if we say that $S$ is ignorant that $p$-we always mean that $S$ is factively ignorant that $p$, that is, ignorant that $p$ is true. Of course, we might introduce a new use of the word 'ignorant', but it will then count as a term of art and we should not do so unless it has some theoretical use.

Third, Le Morvan claims that someone who falsely believes that $p$ is ignorant that $p$, because someone who falsely believes that $p$ is ignorant that $p$ 's truth-conditions are satisfied. After all, such a person is ignorant that those truth-conditions are not satisfied. Thus, if someone falsely believes that he was robbed by a Canadian, then he is ignorant that he was robbed by a Canadian. To me, this seems just confused. If someone says "Sam was ignorant that he was robbed by a Canadian", then that conversationally implies that Sam was in fact robbed by a Canadian. Of course, if Sam falsely believes that he was robbed by a Canadian, then Sam is ignorant as to whether or not he was robbed by a Canadian. But we would describe that by saying "Sam is ignorant that he was not robbed by a Canadian" or "Sam is ignorant as to whether or not he was robbed by a Canadian" or "Sam falsely believes that he was robbed by a Canadian", but not by saying "Sam is ignorant that he was robbed by a Canadian".

Finally, according to Le Morvan, my claim that one can only be ignorant that $p$ if $p$ is true conflicts with the common idea that we can be ignorant of falsehoods. He provides the following example in support of this thesis. Ulrike Schmidt lived in Eastern Germany during the cold war. The Stasi maintain a lengthy file of her activities and proclivities, but the file also contains many falsehoods. According to Le Morvan, it is natural to say that Schmidt is ignorant of the falsehoods in the file and that her ignorance of those falsehoods is dispelled once she gains access to the file. Again, this seems mistaken to me. Surely, Schmidt was ignorant that the file contains those falsehoods. But notice that it is a truth that the file contains such falsehoods. What about the falsehoods themselves? Let one of them be the proposition that Schmidt had contacts with the American government. As a matter of fact, Schmidt had no such contacts and she knows that she had no such contacts. Now, is Schmidt ignorant of this falsehood? That is, is she ignorant that she had contacts with the American government? Of course, not. She is fully aware and knows that she has no contacts with the American government. We should not confuse that ignorance with ignorance of the fact that the file contains such a false claim about her. Hence, we have not been given a convincing reason to reject my thesis that one can only be ignorant of truth. 


\section{The Linguistic Argument}

My first argument-which I call the Linguistic Argument-for the New View on ignorance has three steps. First, cases of justified true belief that are close to knowledge (I call them A-type cases), such as Gettier-cases, do not seem to be cases of ignorance. Second, cases of mere true belief (I call them B-type cases) do not seem to be cases of ignorance either. Third, if both cases of justified true belief that are close to knowledge and cases of mere true belief are not cases of ignorance, then in-between cases (e.g. cases of true belief with some justification) will not be cases of ignorance either. Le Morvan seems to accept the third step, so we disagree only on the first and second steps.

Le Morvan suggests that one's intuition that $S$ is not ignorant that $p$ in A-type cases and B-type cases might be due to the fact that in such cases $S$ is not propositionally ignorant that $p$, even though $S$ is factively ignorant that $p$. In response, I would like to insist that a confusion between propositional ignorance and factive ignorance is not the origin of the adherent to the New View's intuition that in A-type cases and B-type cases $S$ is not ignorant that $p$. Of course, if one truly believes that $p$, one is not propositionally ignorant that $p$, that is, one is not ignorant what the truth-conditions of $p$ are. Both adherents of the New View and adherents of the Standard View agree on that. The adherent of the New View, however, has the additional linguistic intuition that in such cases $S$ is not factively ignorant, that is, not ignorant of the fact that $p$ is true. Thus, in a Gettier-case in which I justifiedly and truly believe that it is 3 p.m. without knowing that it is 3 p.m., I am not ignorant of the fact that it is 3 p.m., although I am ignorant of all sorts of facts in the neighbourhood. And if Jim, the Miami truck driver, believes without any good reason that the next president of the United States lives in Miami and that is in fact true, then Jim is not ignorant of the fact that the next president of the United States lives in Miami, although he is ignorant of all sorts of facts in the neighbourhood, such as who that next president is, why that person will be the next president, and what evidence there is for that person's being the next president.

It is hard to provide further support for the claim that what drives the adherent of the New View when it comes to the Linguistic Argument is a linguistic intuition about factive rather than merely propositional ignorance. She cannot provide similar cases in which some is propositionally ignorant but not factively ignorant and, thereby, strengthen her claim that her intuition is really one about factive ignorance. This is because the absence of factive ignorance - that is, a true belief - seems to rule out propositional ignorance, for if one truly believes that $p$, then one is not ignorant what the truth-conditions of $p$ are. The adherent of the Standard View, then, should believe the adherent of the New View on his word, when the adherent of the New View affirms that her linguistic intuitions in A-type and B-type scenarios are really intuitions about factive rather than propositional ignorance.

\section{The Excuse Argument}

Le Morvan argues that my second argument for the New View-which I call the Excuse Argument - fails and claims that the tables can even be turned on the New 
View. Briefly, the Excuse Argument runs as follows. It is widely agreed that ignorance of relevant propositions provides an excuse, at least a partial one. But mere true belief provides no excuse, not even a partial one. However, on the Standard View mere true belief counts as ignorance. Hence, the Standard View has an implication which is widely rejected among philosophers. This is a good reason to abandon the Standard View and adopt the New View on ignorance.

The example I provided in support of this claim is the following. Imagine that Matthew is about to destroy an old barn which is in fact a historical monument. If he blamelessly disbelieves that it is a historical monument, he is excused for destroying the barn. If he blamelessly suspends judgement on whether it is a historical monument and still destroys it, he is blameworthy, but not as blameworthy as he would have been if he had believed that it was a historical monument. Disbelieving ignorance and suspending ignorance, then, provide respectively a full and a partial excuse. But if Matthew merely truly believes that it is a historical monument, he is not at all excused: he is as blameworthy as he would have been if he had known that it is a historical monument. But on the Standard View, true belief that fails to be knowledge counts as ignorance. Hence, the Standard View contradicts the widely accepted thesis that ignorance provides at least a partial excuse.

Le Morvan replies that not just any kind of blameless ignorance excuses: Matthew's blameless ignorance of the old barn's being a historical monument would not excuse him for assassinating President Obama. A piece of ignorance excuses only if it is exculpatorily relevant. True belief that the old barn is a historical monument, however, is clearly exculpatorily irrelevant for destroying the old barn. Hence, even though that true belief is, on the Standard View, an instance of ignorance, because it fails to be a case of knowledge, that does not refute the widely accepted view that blameless ignorance provides at least a partial excuse. This is because Matthew's true belief that the old barn is a historical monument is clearly exculpatorily irrelevant: it does not excuse him at all.

I agree, of course, that not every instance of ignorance is exculpatorily relevant. It does not follow, though, that Matthew's true belief that the old barn is a historical monument (let us call this proposition $p$ ) is exculpatorily irrelevant. In fact it seems that it is exculpatorily relevant, for ignorance of proposition $p$ is what could possibly excuse Matthew for destroying the old barn. If Matthew blamelessly disbelieves that true proposition $p$, then that ignorance excuses him for destroying the old barn. If he blamelessly suspends judgement on the true proposition $p$, then that ignorance partially excuses him for destroying the old barn. If he is blamelessly deeply ignorant that $p$ is true-if he neither believes that $p$ nor disbelieves that $p$ nor suspends judgement on $p$, say, because he cannot even grasp $p$ - he is clearly fully excused for destroying the old barn. But if he truly believes that $p$, then he is clearly blameworthy for destroying the old barn-unless further excuses, such as compulsion, hold. True belief that $p$ is exculpatorily relevant, then, in that it renders Matthew blameworthy unless further excuses hold. On the Standard View, however, if Matthew merely truly believes that $p$, then he is ignorant that $p$. And it is widely accepted that ignorance provides at least a partial excuse. But his true belief clearly does not excuse him at all. Hence, the Standard View should be rejected.

Le Morvan also claims that the Standard View can explain why certain cases of true belief count as cases of blameworthy ignorance, while the New View cannot, 
because on the New View true beliefs do not count as cases of ignorance. He gives the following example in support of his claim. A father is engrossed for hours in watching a football game on television and believes, merely as a result of wishful thinking, that his toddler daughter is playing somewhere safe. In fact, she is playing somewhere safe, so that his belief happens to be true. The best analysis of this situation seems that the father is blameworthily ignorant that his daughter is playing somewhere safe. On the New View, however, the father's belief cannot count as an instance of ignorance - and, hence, not as a case of blameworthy ignorance - for on the New View true beliefs that fall short of knowledge do not count as ignorance.

As it seems to me, however, the New View has enough resources to explain why the father of this young toddler is culpable. First, of course, he is culpable for his negligence: he should have checked regularly whether his daughter is safe. Second, he is blameworthy for believing merely on the basis of wishful thinking that his daughter is safe: if he were more conscientious, he would not believe that on such a basis. But would we not describe this father as ignorant? Maybe we would. But then there are all sorts of things that he is ignorant of: where precisely his daughter is, what she is playing with, and so forth. And, of course, the adherent of the New View could admit that this father should have known that his daughter is safe rather than merely truly believing it on the basis of wishful thinking. Hence, there is plenty of room to explain that the father is blameworthy in several ways, without claiming that he is culpably ignorant that his daughter is playing somewhere safe.

\section{Two Further Objections}

Finally, let me discuss two further objections that one might level against the New View. ${ }^{5}$ Since they are closely related, let me first sketch each of them and then discuss them. First, if true belief does not count as ignorance, then one can reduce one's ignorance by randomly believing all sorts of propositions. In case one happens to believe a true proposition, one is no longer ignorant of the truth of that specific proposition. On the New View, if one disbelieves a proposition, suspends belief on a proposition, or neither believes nor disbelieves nor suspends belief on a proposition, one is ignorant of that proposition in case it is true. But then, if one wants to remove one's ignorance, one should believe as many propositions as one can. A substantial number of these propositions will be true, so one will loose many instances of ignorance. But it seems implausible that one could remove one's ignorance so easily and in such an irrational way.

Second, imagine that there are two brothers Adam and Bert. Adam is intellectually sloppy and credulous: he easily believes a proposition, even if there is too little evidence for it. His brother Bert is much more intellectually conscientious and critically thinks through what evidence he has for many propositions that he considers. As a result of that, Adam believes a much larger number of propositions than Bert, who suspends belief on many propositions. Another result is that Adam holds more true beliefs than Bert, even though he also holds many more false beliefs than

\footnotetext{
${ }^{5}$ They were brought forward after presentations that I gave on several occasions and in conversations that I had with people on the issue.
} 
Bert. It follows from the New View, but not from the Standard View that Adam is less ignorant than Bert, for there are more propositions that Adam believes. But this is counterintuitive: it seems that intellectual sloppiness and credulousness do not make one less ignorant than someone who is intellectually thorough and critical.

In response to these two objections, let me stress that my analysis of ignorance is an analysis of ignorance of a particular proposition. I have not provided an analysis of ignorance as a more general property or trait of a person. The above two examples, however, are both about a person's ignorance in general. Hence, both examples and both objections based on these examples are irrelevant to the New View.

I think, though, that there are further reasons to think that the objections are not as convincing as they might initially seem. Imagine that there is someone who disbelieves all false propositions and who believes all true propositions. One could even add to this scenario that this person does not know all true propositions, say, because this person's belief are unreliably produced: in nearby possible worlds many of her beliefs are false (if some kind of reliabilist account of knowledge is correct). Now, would be describe this person as ignorant of something? It seems to me that we would not. What would she possibly be ignorant of? There is no truth that she fails to believe and no falsehood that she fails to disbelieve. On an internalist account of knowledge, this person might even be indistinguishable from someone who knows all true propositions: on certain internalist accounts, if one believes all true propositions, then one knows all true propositions. This is because if one believes all true propositions, one will also believe every truth about one's evidence, the evidential relation between one's evidence and the proposition in question, and so forth. Thus, both on externalist and many internalist accounts of knowledge, someone who believes every truth and disbelieves every falsehood does not seem ignorant of anything.

If this is true, however, then it seems plausible that by acquiring more true beliefs, one becomes less ignorant: every true belief that one acquires is one little step in the direction of believing all truths and, thereby, ridding oneself of all ignorance. But then how can we explain the intuitive plausibility of the two objections that I sketched above? As to the first objection, we should distinguish between scope and degree of ignorance. If one somehow succeeds in voluntarily believing a large number of propositions and, thereby, acquires certain true beliefs and, hence, reduces one's ignorance, one reduces the scope of one's ignorance: there are less propositions that one is ignorant of (even though there may remain an infinite number of propositions that one is ignorant of). However, one also acquires certain false beliefs that one did not have before. Hence, even though one may become ignorant of less propositions, one's degree of ignorance may not thereby become lower. It may even increase, if it is true that one is more ignorant if, say, one disbelieves a true propositions than if one suspends belief on a true proposition.

As to the second objection, if Bert is intellectually more conscientious than Adam, then (i) he is probably less ignorant than Adam on certain propositions and (ii) he is less likely to acquire false beliefs on certain issues than Adam. As to (i), he presumably knows that he is conscientious, he knows how to investigate something carefully, he knows that certain things ought to be carefully studied before one 
believes them, and so forth. Presumably, these are things that Adam does not know (or truly believe). Part of the intuition that Bert is less ignorant than Adam, then, can be explained by the fact that there are probably certain propositions that Bert knows or truly believes and that Adam does not know or truly believe. As to (ii), if Bert is less likely to acquire false beliefs on certain issues, then his degree of ignorance may be lower, even though he might be ignorant of a higher number of propositions, as I pointed out above. Finally, we should be careful not to equate ignorance with intellectual blame and lack of ignorance with intellectual praise or blamelessness: one may be epistemically blameworthy for removing some kind of ignorance and one may be epistemically praiseworthy or at least epistemically blameless for remaining ignorant on some topic.

I admit that these further criticisms of the two additional arguments against the New View are rather sketchy. I take it, though, that in conjunction with my major objection - the objection that my analysis is an analysis of ignorance of a particular proposition rather than an analysis of ignorance as a person's intellectual character trait-I have provided enough reason for the adherent of the New View not to be worried about these two arguments.

\section{Conclusion}

In this paper, I have provided a vindication of the New View, on which ignorance is lack of true belief rather than lack of knowledge. I agreed with Pierre Le Morvan that the distinction between propositional ignorance and factive ignorance makes sense. However, propositional ignorance turns out to be just a subspecies of factive ignorance. Moreover, the concept of propositional ignorance is not one we use in ordinary discourse. Of course, it can be used as a philosophical concept, but we should not do so unless it has clear theoretical use. And I argued that all the work can be done by using the concept of factive ignorance.

Next, I pointed out that the intuition of the adherent of the New View about cases of true belief that fall short of knowledge are really intuitions about factive rather than propositional ignorance. Subsequently, I defended my Excuse Argument for the New View by arguing that true belief is exculpatorily relevant: a true belief in a proposition $p$, where disbelief that $p$ or suspension on $p$ would provide at least a partial excuse, is relevant in that it renders one blameworthy for one's action, unless further excuses hold.

Finally, I replied to two closely related objections against the New View, namely that it seems false that one can reduce one's ignorance by arbitrarily believing as many propositions as possible and that it seems false that an intellectually conscientious and critical person is more ignorant than an intellectually sloppy and credulous person just because the latter has more true beliefs. I replied that the New View provides an analysis of a person's ignorance of a particular proposition, not of a person's ignorance as an intellectual character trait. Moreover, we should distinguish between scope and degree of ignorance: one can reduce the scope of one's ignorance by arbitrarily or culpably coming to believe certain propositions that are true. It does not follow that one's degree of ignorance is lower, for in doing so, one will also acquire more false beliefs and it seems that someone who believes a false proposition 
is more ignorant than someone who suspends belief on that proposition. I conclude that the New View stands undefeated.

Open Access This article is distributed under the terms of the Creative Commons Attribution License which permits any use, distribution, and reproduction in any medium, provided the original author(s) and the source are credited.

\section{References}

Le Morvan, P. (2011). On ignorance: a reply to Peels. Philosophia, 39(2), 335-44.

Le Morvan, P. (2011). On ignorance: a vindication of the standard view. Philosophia, 40, forthcoming. doi:10.1007/s11406-011-9330-9.

Peels, R. (2010). What is ignorance? Philosophia, 38(1), 57-67.

Peels, R. (2011). Ignorance is lack of true belief. Philosophia, 39(2), 345-55. 